\title{
The problems of efficiency and linguistic discrimination in the coordination of firms*
}

\author{
CARLOTA SOLÉ, AMADO ALARCÓN, ALBERT TERRONES, and \\ LUÍS GARZÓN
}

\section{Abstract}

This article deals with the strategies of linguistic coordination of four enterprise models located in Catalonia (Spain), unequally affected by the mobility of factors of production. We analyze the linguistic regimes of each one of these models paying special attention to the linguistic criteria of selection and promotion of personnel. Based on the data obtained, we identify two typologies of companies, each one with a different degree of emphasis on communicative efficiency and on strategies of control through practices of linguistic discrimination.

\section{Introduction: languages and factor mobility}

This article presents the results of case studies involving firms located in Catalonia (Spain, European Union), in which we analyze the problems concerning the efficiency and distribution of resources based on ethnolinguistic criteria. Scholarly studies, especially from Quebec, have analyzed linguistic demands in bilingual contexts in the world of business, and highlight that such demands are conditioned by: 1) the language of consumer markets; 2) the languages of the technologies used at work; and 3) the language of the owners of the firms (Hocevar 1975; Breton and Mieszkowski 1979; Vaillancourt 1992; Leblanc 1994). Here we deal with the more complex context of the linguistically heterogeneous $\mathrm{Eu}-$ ropean Union. This complexity increases with the mobility of the factors of production (clearly present in the Economic and Monetary Union) and can be seen in the increasing linguistic diversity of firms. In fact, as we explain in the article, mobility of factors of production places owners, workers, and customers from different linguistic communities in the same space - physical or virtual - in which they must coordinate their activities. 
The Economic and Monetary Union has brought with it the elimination of barriers to the free movement of factors of production and promotes an increase in the number of linguistic contacts between Europeans. From an economic point of view, interest resides in the cultural and linguistic barriers between firms that limit the mobility of labor necessary for the European market for factors of production to be able to act as an efficient mechanism for the allocation of resources (Christie et al. 2001; Hagen 1997; European Commission 2002). In the search for efficiency, it is difficult to adopt the solutions of other large markets such as the United States, where the dominant position of the English language over ethnic minorities frequently leads to what are called "English-only work rules" as a coordination mechanism in firms (Dicker 1998). In addition, the problem of linguistic diversity as a barrier to efficient allocation increases with the centrality of the management of information and knowledge and thus with the linguistic intensity of the production process (Harris 1998a, 1998b). On the other hand, even though economic efficiency is a central problem, we should not obviate the problem of equality between linguistic groups. Thus, the problem of linguistic justice has arisen to the extent that the process of globalization generates both winning and losing linguistic groups. From this point of view, the problem is not so much the disappearance of minority languages, but rather the position in which members of each linguistic group find themselves within the new international order (Pool 1991; Van Parijs 2002).

Based on these considerations, we have established the following objectives: 1) to analyze the criteria for recruitment and promotion in companies according to their position with respect to international flows of factors (national origin of capital, the international distribution of consumer markets, and the ethnolinguistic origin of workforces), and to the linguistic intensity of the productive processes; 2) to base linguistic choices and strategies on the two-fold premise that business practices are the outcome of firms' economic goals as a corporate actor and of the differentiated interests of the various ethnolinguistic groups involved in the firm; and 3) to specifically address the question of the effects of the enlargement of markets on linguistic strategies and results of firms. It should be pointed out that Catalonia is an example of the lack of success of public regulation of linguistic exchanges within the business world (Solé and Alarcón 2001).

We consider that linguistic groups within the productive structure are not homogeneous wholes that react in the face of structural changes, regardless of the position held by each actor in the social structure and in the international economy. Thus, the main hypothesis ${ }^{1}$ guiding our research is that individual linguistic choices depend on the individual's position within the firm, on decisions made by firms concerning organizational 
structures, and on the position of the firm within the structure of world competition. This position with respect to the structure and unequal distribution of linguistic capital conditions choices concerning the functions of utility in the business world, which we will elaborate on in the following sections.

\section{Communicative efficiency and effectiveness}

According to Dhir and Savage (2002), organizations choose as a working language that which offers the most efficient rates of knowledge creation and management in a competitive environment. Linguistic efficiency is associated, since the work of Marschak (1965), with communicative efficiency, which is defined as the capacity to transmit a specific quantity of information in less time than with another language. More generally and widely accepted, the concept of communicative efficiency is generally associated with linguistic homogenization as a means of reducing transaction costs (Breton and Mieszkowski 1979). Focusing on the effects of the market, linguistic homogenization as a strategy to attain efficiency has been analyzed in the context of the monopolistic tendencies displayed by the means of exchange (Carr 1985), the effects of network externalities (Church and King 1993), and of the way in which languages are considered to be hyper-collective goods (de Swaan 1993, 1998).

Each language has a structural position - defined as the number of people who speak it as a mother tongue and lingua franca - that determines the interest in learning that language, and that de Swaan (1993) defines as "communicative potential." Van Parijs (2003) has developed the concept of "maximin communication," according to which actors' choices seek to maximize the minimum expected gain. This linguistic efficiency strategy involves choosing as a language of communication that which is at least minimally understood by one's audience. In other words, attempts are made to minimize the number of people excluded in the process of communication. The question centers on the extent to which the maximin criterion (minimum exclusion) is fulfilled within firms, and the extent to which firms are affected by factors other than those relating to communicative efficiency.

From the perspective of communicative effectiveness, we consider that the choice of languages in firms is not necessarily regulated by maximin criteria due to the high level of linguistic specificity and intensity of goods and services that characterize the information and knowledge society. The effectiveness strategy is contained within the minimax criterion. Following this criterion, an actor chooses the strategy that minimizes the 
maximum expected loss. It involves non-adaptive strategies, such as those analyzed by Colomer (1990), whereby individuals grant a high value to the use of their mother tongue and prefer to establish communication in such a language despite being proficient in others. Several studies highlight these linguistic preferences for their mother tongues among consumers (Vaillancourt 1985, 1989; McManus 1985).

Linguistic intensity is the component of communication necessary for the production and commercialization of goods that determines the internal linguistic costs (in production management) and the external ones (in relation to suppliers and markets). The maximin strategy (efficiency) is viable where there is a low linguistic intensity involved in the product or process. On the other hand, a minimax strategy (effectiveness) is to be recommended where there is a high degree of linguistic intensity; that is, in those markets where the use of majority languages is highly valued, it is advisable to employ workers who are specialized in such languages. In this respect, within the context of the unification of markets, Harris (1998a), based on the Hecksher-Ohlin model, points out that the trade in services and, in particular, the localization of such services in other language communities generate demand for a workforce that is proficient in many languages, although not necessarily so in the lingua franca. At the same time, Kingscott (1990) argues that large firms, especially those in the most advanced sectors (telecommunications, financial services, and certain consumer goods), pay closest attention to language, since they are companies that are obliged to maximize the competitive potential of new informational technologies. In addition, such firms target markets that are culturally and linguistically heterogeneous, and commercialize goods and services with a high degree of linguistic intensity.

\section{The allocation of resources and linguistic discrimination}

As an exchange community gets bigger, as is the case of the EU, a fundamental question must be faced: what is the optimum number of participants in the community? or, in other words, when and how should membership be increased? Political sociology of language addresses the problem, which is linked to the consequences of languages for the Weberian concept of 'social closure'; that is, the interest in limiting the size of or access to the group as a means of socially segmenting access to resources. Social closure is articulated by the political adoption or suppression of barriers to exchange by means of norms that establish the right to control access to resources (Coleman 1990). From this perspective, economic and linguistic power is the property of the ruling class. Access to the ruling 
class is regulated by the difficulty in acquiring the language of this class. Such difficulty is variable and is subject to the decisions of the ruling class (Pool 1993). Thus, the problem in organizations is not always to seek solutions that allow transaction costs to be minimized, but rather barriers to exchange also arise due to rational interests concerning the distribution of resources between different groups within an organization.

Both sociology and political science have analyzed the distribution of resources between linguistic groups within a given framework of interests (De Swaan 1993). The most obvious example is when language is considered to be a barrier to entry into the labor market, especially for jobs in public administration whereby a given linguistic group is favored (Breton 1964, 1978; Solé and Alarcón 2001). According to Myers-Scotton (1982, 1993), elite closure is a form of strategic social mobilization by which individuals in power establish or maintain their privileges. Elite closure is possible due to three universal sociolinguistic propositions: 1) not all individuals from the same community speak the same linguistic varieties; 2) the same linguistic varieties in a community have different situational uses; and 3) all types are either positively or negatively valued by the members of the community depending on the specific kind of interaction. Elite closure is a situation that is observed in large multinational companies, in which a global ruling elite comes into contact with a locallyrecruited workforce and also with local firms employing foreign workers.

Within the context of firms, a taste for discrimination by employers has been highlighted, both among owners and workers, that produces segregation between ethnolinguistic groups within firms. There is evidence of how wage discrimination of a given ethnic group leads to the segregation of ethnic groups between firms (Becker 1971), to vertical stratification (Arrow 1972) as well as between professional groups (Lang 1986). Currently, it is considered that the preference for discrimination must have some useful function, which, in the case of languages, is linked to the productivity of each group (Raynauld and Marion 1970) and to the minimization of the transaction costs derived from linguistic differences (Lang 1986, 1993). Hocevar (1975) distinguishes linguistic minorities from other kinds of minorities and insists on the role of language as means of communication. In this respect, he concludes that differences in remuneration between linguistic majorities and minorities are not necessarily due to discrimination: wage differentials can equally be explained by the linguistic specificities of factors of production, of goods and services, and of the mode of production.

The tendency towards the vertical disintegration of organizations, the increased needs for horizontal communication, and the greater importance of knowledge management in the production process are factors 
that challenge vertical and horizontal linguistic segmentation along ethnic and linguistic lines. In the case of multinational firms and of all those firms in which the number of employees from different linguistic groups increases, the question that arises from our theoretical framework centers on when to adopt an international lingua franca for internal communication and thus abandon the traditionally dominant language associated with the national origin of the firm in question; in other words, when to abandon the language of the owners and top management as an instrument of coordination in favor of the languages of other linguistic groups in the organization.

Finally, in addition to the above, we must distinguish the use value and the exchange value of language. The former is the capacity to take advantage of certain resources. Such capacity is conditioned by the position of each agent in the economic and social structure that, in turn, conditions such strategies as the maximization of communicative efficiency, the linguistic efficiency in the distribution of linguistically intensive goods or the maximization of control. On the other hand, the exchange value of languages is the structural value of languages that is dependent on the world-wide distribution of a language, the level of technological development and the degree of factor mobility at any given time. Thus, the position of each agent in terms of the structure must be taken into account if we are to fully understand linguistic choices.

\section{Model of analysis}

We have taken into consideration three variables that characterize the problem of coordination and which have consequences for the linguistic organization of business activity: a) the size, as a key factor that has historically conditioned the processes of linguistic rationalization and bureaucratization; $b$ ) the degree of internationalization of the productive process and of markets, a factor that determines the degree of internal and external linguistic heterogeneity; c) the linguistic intensity, which is especially affected by the degree to which information and knowledge are centralized during the productive process. By combining the variables, we have selected the following production centers as settings for the observation of linguistic regimes.

In terms of the question of coordination and discrimination, we have taken into account the following variables: a) the degree of hierarchy of the organizational structure, to the extent that this conditions relations and communication needs within the workforce (give and follow instructions versus the sharing and co-production of information and 
Table 1. Coordination, efficiency and effectiveness

\begin{tabular}{|c|c|c|c|}
\hline & & \multicolumn{2}{|c|}{ Size and multinational nature } \\
\hline & & Large multinational firms & Small localized firms \\
\hline \multirow[t]{4}{*}{$\begin{array}{l}\text { Linguistic } \\
\text { intensity of } \\
\text { production } \\
\text { process and } \\
\text { products }\end{array}$} & High & $\begin{array}{l}\text { Label: Ethnocentric companies } \\
\text { Production centers belonging } \\
\text { to multinational companies } \\
\text { in the new information and } \\
\text { communication technology } \\
\text { sectors }\end{array}$ & $\begin{array}{l}\text { Label: Small- and medium- } \\
\text { sized firms (SMEs) in the } \\
\text { health sector } \\
\text { SMEs in the health sector } \\
\text { located on the touristic } \\
\text { coast of Catalonia (Spain) }\end{array}$ \\
\hline & & $\begin{array}{l}\text { Label: Ethnocentric firms in } \\
\text { transition to geocentric ones }\end{array}$ & \\
\hline & Medium & $\begin{array}{l}\text { Production centers belonging } \\
\text { to multinational companies } \\
\text { in the sector of basic } \\
\text { chemical products (organic } \\
\text { and inorganic) }\end{array}$ & \\
\hline & Low & $\begin{array}{l}\text { Production centers belonging } \\
\text { to multinational firms in the } \\
\text { automotive sector }\end{array}$ & $\begin{array}{l}\text { Label: Industrial cluster } \\
\text { Furniture industry }\end{array}$ \\
\hline
\end{tabular}

knowledge); and b) the degree of preference for external and internal labor markets, which conditions to a large extent the choice between language training within the firm and acquiring language capital in the labor market. In addition, we have considered a third variable: c) the ethnolinguistic composition of the groups that participate in the firm (owners and workers), which depends both on migrations for reasons of work, and on the presence of a group of expatriate employees in the case of multinational firms. We have distinguished three groups of individuals: autochthonous workers, those from the EU, and those from EU-candidate states. Members of such groups find themselves at an advantage or at a disadvantage with respect to other linguistic groups according to the setting. In terms of the groups of foreign workers, we have distinguished between those sharing the same nationality as the ownership of the firm, and "elite bilinguals." This differentiation is fundamental in that the former constitute an elite group of employees that provide global management for the firm through a process of rotation through the different subsidiaries of the firm throughout the world (internal labor markets). On the other hand, the group labelled elite bilinguals mainly describes a workforce that is recruited from the external labor market, with employees charged with middle-management tasks within multinational firms, although they are not necessarily from the same national background as the firm. 
Table 2. Coordination and discrimination

\begin{tabular}{llll}
\hline & & $\begin{array}{l}\text { More hierarchical } \\
\text { structures and } \\
\text { internal labor } \\
\text { markets }\end{array}$ & $\begin{array}{l}\text { More horizontal } \\
\text { structures and } \\
\text { external labor } \\
\text { markets }\end{array}$ \\
\hline $\begin{array}{l}\text { Foreign } \\
\text { linguistic } \\
\text { groups }\end{array}$ & $\begin{array}{c}\text { Same nationality as the } \\
\text { ownership of the firm } \\
\text { (Germany and the United } \\
\text { States) }\end{array}$ & $\begin{array}{c}\text { Ethnocentric } \\
\text { company }\end{array}$ & $\begin{array}{c}\text { Geocentric } \\
\text { company }\end{array}$ \\
& $\begin{array}{l}\text { Bilingual elites (from the EU: } \\
\text { France, Belgium, Germany, } \\
\text { Sweden). }\end{array}$ & $\begin{array}{l}\text { Ethnocentric firms } \\
\text { in transition to } \\
\text { geocentric ones } \\
\text { Industrial cluster }\end{array}$ & $\begin{array}{c}\text { SMEs from the } \\
\text { service sector }\end{array}$ \\
\hline
\end{tabular}

Immediately below, we have detailed the essential characteristics of each one of the linguistic settings analyzed and the distribution of the participants of the ten discussion groups used.

\section{Linguistic regimes}

For analytical purposes, the following figure shows a stylized distribution of the most significant linguistic groups in the different organizational settings according to their position in the firm. Firstly, we observe a high degree of ethnostratification in the firms analyzed corresponding to the national origin of the firm, especially in terms of higher management. Secondly, we can see how the group called "elite bilinguals" adopts a key position in the model of firms in transition and in geocentric firms. Thirdly, in the case health sector SMEs, a segregation into separate firms can be observed. Fourthly, the group of Romanian workers from outside the EU suffer discrimination in the place of work in firms in the industrial cluster. Figure 1 shows such results in more detail.

\subsection{Ethnocentric companies}

In the first setting, reference is made to global companies, also called ethnocentric ones, in which there exists a high degree of international coordination of production and a low level of autonomy for subsidiaries. The client base is considered to be a global whole and, as such, economies of scale are sought to be maximized. No specific products are available for different national markets; instead products are aimed at different social 
Table 3. Summary of the principle characteristics of the settings analyzed

\begin{tabular}{|c|c|c|c|c|c|}
\hline Label & $\begin{array}{l}\text { Ethnocentric } \\
\text { multinational } \\
\text { companies }\end{array}$ & $\begin{array}{l}\text { Ethnocentric } \\
\text { companies in } \\
\text { transition to } \\
\text { geocentric ones }\end{array}$ & $\begin{array}{l}\text { Geocentric } \\
\text { multinational } \\
\text { companies }\end{array}$ & Industrial cluster & $\begin{array}{l}\text { SMEs from the } \\
\text { health sector }\end{array}$ \\
\hline Companies analyzed & $\begin{array}{l}\text { Seat (Volkswagen), } \\
\text { Mercedes }\end{array}$ & $\begin{array}{l}\text { BASF, Bayer, } \\
\text { Henkel }\end{array}$ & $\begin{array}{l}\text { Agilent } \\
\text { Technologies }\end{array}$ & $\begin{array}{l}10 \text { SMEs from } \\
\text { the furniture } \\
\text { industry }\end{array}$ & $\begin{array}{l}6 \text { small health-sector } \\
\text { firms }\end{array}$ \\
\hline $\begin{array}{l}\text { Distribution of the } \\
\text { participants in } \\
\text { discussion groups }\end{array}$ & Groups 1,2 , and 5 & $\begin{array}{l}\text { Groups } 3,1,4 \text {, and } \\
5\end{array}$ & $\begin{array}{l}\text { Groups } 1,2 \text {, and } \\
5\end{array}$ & $\begin{array}{l}\text { Groups } 8,9 \text {, and } \\
\quad 10\end{array}$ & Groups 6 and 7 \\
\hline $\begin{array}{l}\text { Nationality of } \\
\text { ownership }\end{array}$ & Germany & Germany & United States & Catalonia (Spain) & Catalonia (Spain) \\
\hline $\begin{array}{l}\text { Characteristics of } \\
\text { the organizational } \\
\text { model }\end{array}$ & $\begin{array}{l}\text { Large manufacturing } \\
\text { firms } \\
\text { High level of } \\
\text { production } \\
\text { decentralization } \\
\text { High degree of } \\
\text { control over } \\
\text { subsidiaries }\end{array}$ & $\begin{array}{l}\text { Large manufacturing } \\
\text { firms } \\
\text { High level of } \\
\text { production } \\
\text { decentralization } \\
\text { Increasing degree of } \\
\text { autonomy for } \\
\text { subsidiaries }\end{array}$ & $\begin{array}{l}\text { Large firms from } \\
\text { the technology } \\
\text { sector } \\
\text { High level of } \\
\text { production } \\
\text { decentralization } \\
\text { High degree of } \\
\text { autonomy for } \\
\text { subsidiaries }\end{array}$ & $\begin{array}{l}\text { Small firms } \\
\text { Specialization } \\
\text { Cooperation }\end{array}$ & $\begin{array}{l}\text { Small firms } \\
\text { Low level of } \\
\text { cooperation } \\
\text { Increasing } \\
\text { specialization }\end{array}$ \\
\hline $\begin{array}{l}\text { Characteristics of } \\
\text { the production } \\
\text { center studied }\end{array}$ & $\begin{array}{l}\text { Assembly of } \\
\text { automobile } \\
\text { components } \\
\text { Distribution center }\end{array}$ & $\begin{array}{l}\text { Production centers } \\
\text { for basic chemical } \\
\text { products }\end{array}$ & Global call center & $\begin{array}{l}\text { Manufacture of } \\
\text { components for } \\
\text { the furniture } \\
\text { industry }\end{array}$ & Public health services \\
\hline Location & $\begin{array}{l}\text { Industrial periphery } \\
\text { of Barcelona }\end{array}$ & $\begin{array}{l}\text { Industrial periphery } \\
\text { of Tarragona } \\
\text { (Chemical Pole) }\end{array}$ & Urban & $\begin{array}{l}\text { Semi-rural South } \\
\text { of Catalonia }\end{array}$ & $\begin{array}{l}\text { Tourist coast } \\
\text { (Balearic Islands } \\
\text { and Costa Dorada) }\end{array}$ \\
\hline
\end{tabular}




\begin{tabular}{|c|c|c|c|c|c|}
\hline $\begin{array}{l}\text { Linguistic intensity } \\
\text { of the products }\end{array}$ & Low & Low & High & Low & High \\
\hline $\begin{array}{l}\text { Linguistic intensity } \\
\text { of the production } \\
\text { process }\end{array}$ & Medium-low & Medium & High & Low & High \\
\hline $\begin{array}{l}\text { Characteristics of } \\
\text { markets }\end{array}$ & $\begin{array}{l}\text { International } \\
\text { Linguistically } \\
\text { heterogeneous, } \\
\text { but not relevant }\end{array}$ & $\begin{array}{l}\text { International } \\
\text { Linguistically } \\
\text { heterogeneous, } \\
\text { but not relevant }\end{array}$ & $\begin{array}{l}\text { International } \\
\text { Linguistically } \\
\text { heterogeneous }\end{array}$ & $\begin{array}{l}\text { State-wide, and } \\
10 \% \text { European } \\
\text { Linguistically of } \\
\text { little relevance }\end{array}$ & $\begin{array}{l}\text { Native population } \\
\text { and international } \\
\text { tourists } \\
\text { Linguistically } \\
\text { relevant }\end{array}$ \\
\hline
\end{tabular}

Source: Own, 2004 


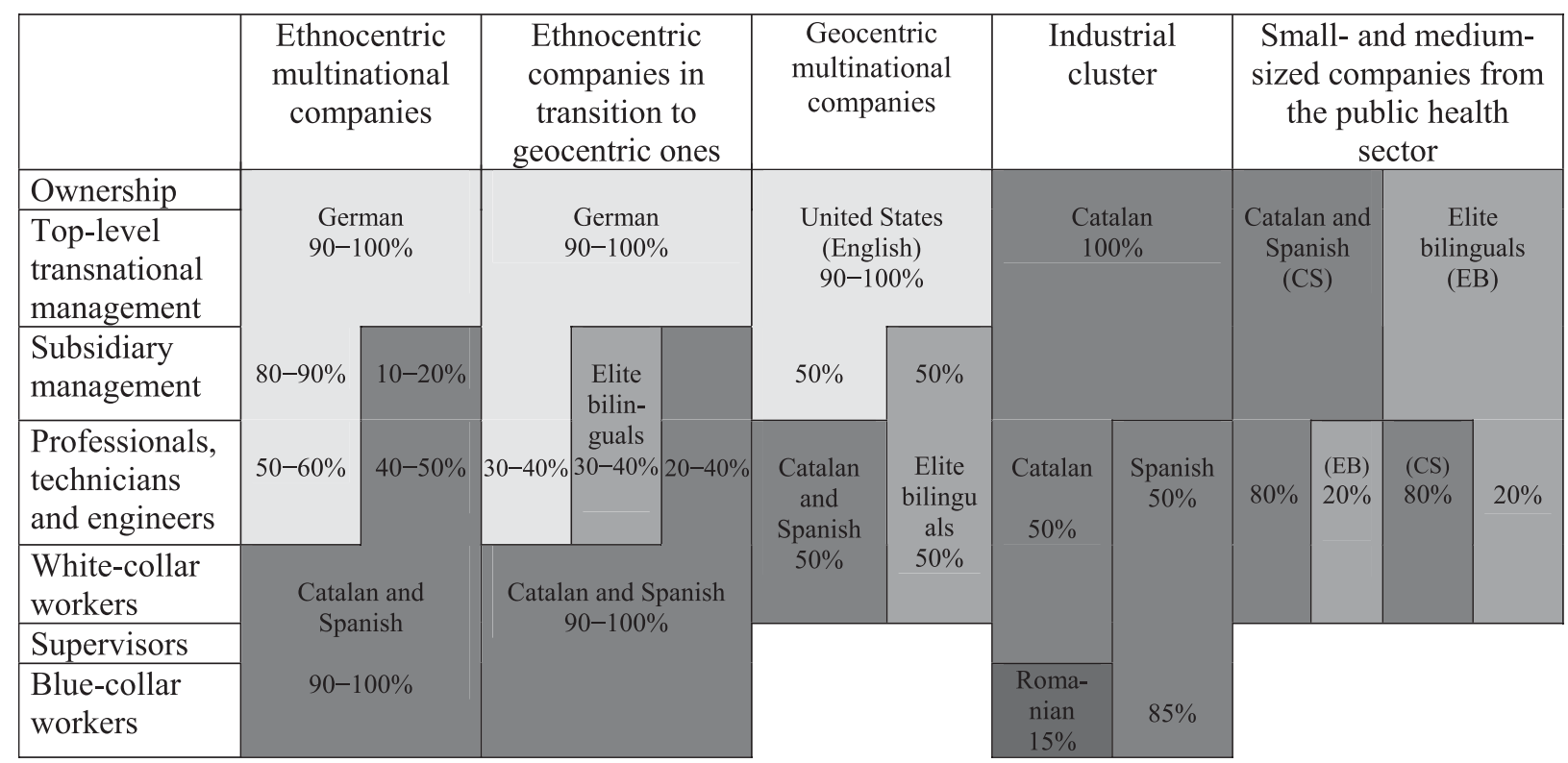

Figure 1. The position and proportion of different ethnolinguistic groups in the firms studied 
strata on a global basis (Barlett and Ghoshal 1989; Pla Barber 1999). Such firms are called ethnocentric, since management is based upon practices from one specific country, that of the firm's origin. Identity is characterized by values, a language and top management that are from the same national background and that are located both in the parent company and at the top of the various centers that the company possesses in different countries. In the cases studied, the national background was German, and all major decisions are taken and transmitted to the management of the subsidiaries in this language. This constitutes an asymmetric regime in which strategic planning and control and supervision of the development of the subsidiaries takes place at the parent company. As such, decision making within the firm is controlled by the parent company and a management group of the same nationality (Birsl et al. 2003).

In the case of these firms, global coordination is articulated by a high degree of mobility of management within the internal labor market. This implies a model of vertical mobility from the headquarters of firms in Germany to subsidiaries located in other countries and from such countries to the head office in Germany. These internal markets create an elite group of employees with high levels of knowledge of the different production centers. Access to high-level management by non-nationals is only achieved after long periods of working in the parent company, by being proficient in the German language and, above all, by generating close ties with the rest of the management at headquarters. A characteristic feature of these firms is that there is a clear segmentation between international planning and local execution. In our survey, they are industrial firms whose products have a low linguistic intensity. More specifically, the production centers located in Catalonia essentially assemble automobile components, although there is a growing tendency towards a greater role of $\mathrm{R}+\mathrm{D}$ centers. The language of the assembly plants is Spanish and, to a lesser degree, Catalan; that is, the languages of the surrounding geographic area. Foreign language abilities are not required for recruitment and promotion of blue-collar workers. We can highlight the fact that the managers with responsibilities for personnel and, above all, for collective bargaining are autochthonous and constitute a link between the bluecollar workforce and the German management. On the other hand, the function of sales is externalized, and as such the question of the language used in relation to the markets of consumption is not relevant.

To sum up, the specific language used in these firms acquires value as a manifestation of power and identity. The corporate language (German) acts as a barrier to the promotion of native (Spanish) managers, while the local languages (Spanish and Catalan) are practically irrelevant in terms of global coordination strategy. In other words, the local languages 
(Spanish and Catalan) are the languages of workplace relations (of execution), while German is the language of planning, management, and those not covered by collective agreements on pay and conditions. As such, in these cases the value of languages in a firm does not depend on the markets in which the firms operate, nor on the social environment in which the firm is located, nor on the linguistic intensity of the production process or of the product, but rather on the national origin of the firm in question.

\subsection{Geocentric companies}

In the second setting, we find transnational or geocentric companies that also demonstrate a high degree of international coordination of production. However, unlike ethnocentric companies, subsidiary companies are more independent and a greater emphasis is placed on satisfying the specificities of local markets. Ownership becomes more geographically diffuse as the company in question expands internationally and as an increasing number of international top managers are employed. The managers of the subsidiaries enjoy a greater degree of autonomy and decisionmaking is more horizontal, taking place between managers of different subsidiaries. Emphasis is placed on process management and on the need for communication between the different centers. The center that best fits this description in our survey manages the company's client database and offers post-sales services to internal and external clients through the use of new information and communication technologies. From the base in Barcelona (Spain) a global service is offered to the company. This is not an isolated case within the other centers of the company. Each one is highly specialized, offering a range of services - development, marketing, production, accounting - to the other centers located in 30 countries. The objective of the center analyzed is to offer such services in the language of the clients, or at least the majority languages in the areas in which the firm operates (state and market made to coincide). This means that the workforce of the center possesses a high degree of linguistic capital.

Recruitment favors nationals of those markets where the company operates, and as such, we find Brazilians, French, Swedes, etc. among the workforce. In this firm, an international supply of labor takes priority, based on external labor markets. For example, the center in Barcelona constantly demands foreign workers with good knowledge of the local markets in which the firm has clients. In order to recruit, advantage is taken of the symbolic capital of having held the 1992 Olympic games and of its Mediterranean character. Many young Europeans come to Barcelona for cultural or leisure reasons and thus find in these firms a means 
of paying for a prolonged stay in the city. It should be pointed out that the company finds in Spain a more satisfactory regime of labor relations - particularly in terms of salaries - than in Central and Northern Europe. On the other hand, unlike other, cheaper locations, Barcelona offers good infrastructure and an international, trained workforce.

It is the consumer market targeted by the firm that yields value to the languages within the firm. The capital value of language is especially evident for employees, with the languages of state markets the most highly valued. At the same time, English is the language of overall coordination within the company and is widely shared and used by the workforce as a whole due to the horizontal nature of the firm. English is an essential requisite for the entire workforce. We must also highlight the fact that such companies seek employees who have lived in the state-markets in which the firm operates. It is not enough to merely know the language; employees must also be familiar with the characteristic of the market in which they will concentrate their efforts within the company. Thus, firms not only seek human capital, but rather human capital that mobilizes social capital created in other countries; that is, the knowledge of customs and norms of interaction, both formal and informal, specific to each market. Consequently, it is competency in languages that are, in Granovetters' (1985) terms, embedded in the social fabric of each market that becomes highly valued.

\subsection{Ethnocentric multinational companies in geocentric transition}

We have also selected international firms that are difficult to place within the above categories. These are firms that are currently in a phase of transition from an ethnocentric organization to a geocentric one. In such cases, a differential element is the increasing role of a group of professionals and technicians who escape vertical mobility and whose careers move horizontally through the different centers of the company. As firms become increasingly centered on specialized high value-added processes, this group of employees increases its relative importance within the firm. These are German companies in which knowledge of the German language is considered to be a merit in the recruitment process, but not essential. As such, professional and/or technical competence basically takes priority. However, not knowing German clearly conditions promotion to higher management posts.

The increasing internationalization of these firms that are present on the five continents, and the greater importance of horizontal relations between a larger number of workers employed in tasks of development of 
international projects, has meant that English has become more widely used in the management of projects and international meetings since the 1990s. According to those interviewed, the increase in the number of centers, together with a greater linguistic heterogeneity of managers, has allowed non-German managers to become more powerful within the company and to call for a greater role for English as a means of promotion within the company.

\subsection{Industrial cluster}

The industrial cluster of furniture manufacturing situated in the Montsià, a semi-rural district in the south of Catalonia, consists of a group of specialist SMEs that are complimentary and labor intensive. A high degree of cooperation exists between the firms, and as such they complement each other in a non-competitive way throughout the production process. In addition, firms relate to each other and with local institutions through ties of familiarity and friendship which reinforce trust within the local productive system (Porter 1999). The products are of a medium to low quality and are mainly aimed at the state market. Since the 1960s and 1970s competitivity has been achieved through the recruitment of cheap labor. The first source of labor was the immigration of the 1960s and 1970s from the rest of Spain, meaning that the majority of blue-collar workers were Spanish-speaking, while owners and white-collar workers have always been Catalan-speaking. With the end of internal migrations and the rise in demand for furniture at the end of the 1990s, linked to the housing boom in Spain, demand increased and owners were forced to look for new sources of cheap labor, in this case from Romania. Currently, Romanian workers represent approximately $15 \%$ of the total workforce and approximately $10 \%$ of the population of the municipalities of the district where the industry is present.

Unlike the previously-analyzed settings, here we see foreign workers in the lower echelons of the labor structure. These blue-collar workers merely execute the simple orders of the autochthonous supervisors. Communication relations are completely asymmetric, and as one of the participants of the discussion group explained: "In the company, we shut up." The management believes that communication skills are not necessary for these positions, and ignorance of Spanish or Catalan is not a barrier for workers to be recruited. The important thing, according to one manager, is that the person "is a worker." In this respect, the perception exists that these workers from the former socialist republics constitute a docile and hard-working labor force. In none of the firms analyzed has any 
Romanian worker managed to reach non-manual posts within the firm. In such firms, managers undertake a variety of functions, including sales. Worthy of note is the fact that the majority of managers have no knowledge of any foreign languages and on the few occasions in which attempts are made to access overseas markets, sales and marketing must be externalized. Being located in a semi-rural area over $200 \mathrm{~km}$ from Barcelona, and the fact that production has always been aimed at the state market, has contributed to keeping the cluster outside of international production and distribution networks. Even with the arrival of workers with knowledge of other languages, in this case Romanians, the international outlook of local management has not increased. However, current competitivity is based on an international labor force (the Romanian workers) that accepts low levels of pay and working conditions.

The value of different languages is not based on the product or on the production process. Catalan and Spanish become valuable for workers as a means of integration in the local community. In terms of autochthonous groups, we should highlight their complete lack of adaptation to the new situation of open markets in Europe. Catalan continues to be the language of power and prestige in these firms, necessary for professional promotion, and the only language used by the management and owners of the firms.

\subsection{Small- and medium-sized enterprises in the health sector}

We have analyzed a group of SMEs in the health sector located on the Catalan coast that have been affected by the presence of foreign residents. As a consequence of flows of tourists and their settlement on the coast, the client base of these SMEs has become more international. The increase in linguistic complexity has not come about due to internationalization strategies of such enterprises, but has rather been forced upon them by the internationalization of the clients, which has become a challenge for the local firms. This is firstly because health services are very linguistically intensive in the relation between patients and health workers; secondly, because the foreign resident population is very heterogeneous (British, German, Belgian, etc., and more recently from Eastern European countries); and thirdly, because health workers (doctors, nurses, and other workers, such as those in old-age care centers) are limited in their knowledge of languages to Spanish and Catalan. In fact, the medical profession in Spain is heavily influenced by the public health system, in which no knowledge of foreign languages is required, while the Catalan language is regarded as a merit for recruitment and promotion in Catalonia. During their training, such workers did not consider the linguistic 
heterogeneity of coastal Spain, nor the way in which it might affect their working practices.

We have highlighted three business strategies towards linguistic heterogeneity in local markets. The first consists of, in the case of local businessmen and women, specializing on the home market. Up until now, this has been the most common strategy. The second is to employ health workers with knowledge of the respective languages of the resident tourists. In order to do so, mainly auxiliary staff and nurses have been employed to act as intermediaries between doctors and patients. Thirdly, foreignowned firms, specialized in the treatment of the fellow nationals, are beginning to emerge. In such cases, the doctors are basically foreign, with some autochthonous auxiliary staff. The doctors are generally the owners of these firms, in which sharing the language of the patient is considered fundamental for generating trust between patient and doctor. In fact, patients prefer doctors who are fellow nationals. Thus autochthonous professionals see how the opportunities available to them gradually decrease due to their own lack of foreign language skills and to foreign competition.

In Table 4 below, we set out the most relevant aspects of the settings that we have described.

\section{Two sets of linguistic results}

By way of summary, we have observed two clearly distinct differentiated results: 1) reinforcement of linguistic divisions as a means of segmenting resources (ethnocentric multinational companies and the industrial cluster); and 2) strategies designed to increase corporate efficiency and effectiveness by bearing the external transaction costs of accessing linguistically heterogeneous clients (geocentric multinational companies, those in transition and health-sector SMEs), and by reducing internal transaction costs through the de-ethnification of the corporate language (ethnocentric firms in geocentric transition).

The reinforcement of linguistic divisions in Strategy 1 is explained by the fact that the language is a fundamental element in the hierarchic rationalization of the firm and for power relations, all of which condition the forms of professional promotion. Language policy fulfills the function of limiting access to tangible and intangible resources, such as the betterpaid managerial or technical posts and social recognition within the firm. This is a situation of social closure along ethnolinguistic lines. The consequence is the segmentation of the workforce into two highly-identifiable professional and linguistic groups: one centers on the task of planning the dominant linguistic group - while the other carries out such plans - 
Table 4. Linguistic characteristics of the settings analyzed

\begin{tabular}{|c|c|c|c|c|c|}
\hline & Ethnocentric Firms & Firms in transition & Geocentric firms & $\begin{array}{l}\text { SMEs from the } \\
\text { furniture industry }\end{array}$ & $\begin{array}{l}\text { Small health firms } \\
\text { on the Catalan } \\
\text { tourist coast }\end{array}$ \\
\hline $\begin{array}{l}\text { Main working } \\
\text { languages in the } \\
\text { organizations }\end{array}$ & $\begin{array}{l}\text { 1) Corporate } \\
\text { language } \\
\text { (German) } \\
\text { 2) Languages of } \\
\text { the local labor } \\
\text { market (Spanish) }\end{array}$ & $\begin{array}{l}\text { 1) Corporate } \\
\text { language, of the } \\
\text { management } \\
\text { (German) } \\
\text { 2) Language of } \\
\text { international } \\
\text { technical co- } \\
\text { ordination (English) } \\
\text { 3) Languages of local } \\
\text { labor markets } \\
\text { (Spanish) }\end{array}$ & $\begin{array}{l}\text { 1) Corporate } \\
\text { language (English) } \\
\text { 2) Language of } \\
\text { international } \\
\text { technical co- } \\
\text { ordination } \\
\text { (English) } \\
\text { 3) Languages of } \\
\text { state markets }\end{array}$ & $\begin{array}{l}\text { 1) Language of the } \\
\text { local community } \\
\text { (Catalan) } \\
\text { 2) Language of } \\
\text { immigrant } \\
\text { workforce, both } \\
\text { internal and } \\
\text { external (Spanish, } \\
\text { Romanian) }\end{array}$ & $\begin{array}{l}\text { 1) Language of the } \\
\text { local } \\
\text { community } \\
\text { (Spanish and } \\
\text { Catalan) } \\
\text { 2) Language of } \\
\text { foreign residents } \\
\text { (European } \\
\text { languages) }\end{array}$ \\
\hline $\begin{array}{l}\text { Origin of the } \\
\text { exchange value } \\
\text { of the languages }\end{array}$ & $\begin{array}{l}\text { National origin of } \\
\text { ownership and } \\
\text { corporate } \\
\text { identity. Need to } \\
\text { coordinate local } \\
\text { work forces }\end{array}$ & $\begin{array}{l}\text { National origin of } \\
\text { ownership and } \\
\text { corporate identity } \\
\text { Increasing need to } \\
\text { coordinate local } \\
\text { work forces }\end{array}$ & $\begin{array}{l}\text { Increasing need for } \\
\text { global } \\
\text { coordination. } \\
\text { State markets }\end{array}$ & $\begin{array}{l}\text { The community and } \\
\text { the local } \\
\text { productive } \\
\text { environment }\end{array}$ & $\begin{array}{l}\text { Linguistic diversity } \\
\text { of the global } \\
\text { environment }\end{array}$ \\
\hline $\begin{array}{l}\text { Origin of the use } \\
\text { value }\end{array}$ & $\begin{array}{l}\text { Access to } \\
\text { ethnostratified } \\
\text { resources in the } \\
\text { firm }\end{array}$ & $\begin{array}{l}\text { Individual promotion. } \\
\text { Access to } \\
\text { ethnostratified } \\
\text { resources in the } \\
\text { firm }\end{array}$ & $\begin{array}{l}\text { Customer } \\
\text { satisfaction }\end{array}$ & $\begin{array}{l}\text { Access to } \\
\text { ethnostratified } \\
\text { resources in the } \\
\text { firm. Social } \\
\text { integration }\end{array}$ & $\begin{array}{l}\text { Local customer } \\
\text { satisfaction }\end{array}$ \\
\hline
\end{tabular}


Table 5. Distribution of linguistic uses by professional categories

\begin{tabular}{|c|c|c|c|c|c|}
\hline & Ethnocentric firms & Firms in transition & Geocentric firms & $\begin{array}{l}\text { SMEs in the } \\
\text { furniture industry }\end{array}$ & $\begin{array}{l}\text { Small public health } \\
\text { firms on the Catalan } \\
\text { tourist coast }\end{array}$ \\
\hline \multirow[t]{2}{*}{ Management } & Monolingual & Bilingual & Monolingual & Monolingual & Monolingual \\
\hline & $\begin{array}{l}\text { Corporate language } \\
\text { (German) }\end{array}$ & $\begin{array}{l}\text { Corporate language } \\
\text { (German) }+ \\
\text { language of technical } \\
\text { co-ordination } \\
\text { (English) }\end{array}$ & $\begin{array}{l}\text { Corporate language } \\
\text { (English) }\end{array}$ & $\begin{array}{l}\text { Corporate language } \\
\text { (Catalan) }\end{array}$ & $\begin{array}{l}\text { Corporate language } \\
\text { (Catalan, Spanish } \\
\text { or European } \\
\text { languages) }\end{array}$ \\
\hline \multirow{2}{*}{$\begin{array}{l}\text { Technicians, } \\
\text { professionals } \\
\text { and engineers }\end{array}$} & Bilingual $(2+1)$ : & Trilingual: & Trilingual: & Monolingual & Monolingual \\
\hline & $\begin{array}{l}\text { Local languages }+ \\
\text { corporate } \\
\text { language }\end{array}$ & $\begin{array}{l}\text { Local languages }+ \\
\text { language of technical } \\
\text { co-ordination }+ \\
\text { corporate language }\end{array}$ & $\begin{array}{l}\text { Local languages }+ \\
\text { language of } \\
\text { markets }+ \\
\text { corporate language }\end{array}$ & $\begin{array}{l}\text { Corporate language } \\
\text { (Catalan and } \\
\text { Spanish) }\end{array}$ & $\begin{array}{l}\text { Corporate language } \\
\text { (Catalan, Spanish } \\
\text { or European } \\
\text { languages) }\end{array}$ \\
\hline \multirow{2}{*}{$\begin{array}{l}\text { White-collar } \\
\text { workers }\end{array}$} & Monolingual & Bilingual & Bilingual & Monolingual & Bilingual: \\
\hline & Local languages & $\begin{array}{l}\text { Local languages }+ \\
\text { language of technical } \\
\text { co-ordination }\end{array}$ & $\begin{array}{l}\text { Local languages }+ \\
\text { language of } \\
\text { technical co- } \\
\text { ordination }\end{array}$ & $\begin{array}{l}\text { Corporate language } \\
\text { (Catalan and } \\
\text { Spanish) }\end{array}$ & $\begin{array}{l}\text { Corporate language }+ \\
\text { languages of } \\
\text { markets (Catalan, } \\
\text { Spanish or } \\
\text { European } \\
\text { languages) }\end{array}$ \\
\hline $\begin{array}{c}\text { Blue-collars } \\
\text { workers }\end{array}$ & $\begin{array}{l}\text { Monolingual } \\
\text { Local languages }\end{array}$ & $\begin{array}{l}\text { Monolingual } \\
\text { Local languages }\end{array}$ & Do not exist & $\begin{array}{l}\text { Monolingual: } \\
\text { Local languages } \\
\text { Bilingual: }\end{array}$ & Do not exist \\
\hline $\begin{array}{l}\text { Extension of } \\
\text { linguistic } \\
\text { functions }\end{array}$ & $\begin{array}{l}\text { Departmental and } \\
\text { specialized }\end{array}$ & $\begin{array}{l}\text { Affects whole } \\
\text { workforce. } \\
\text { Specialization } \\
\text { according to market }\end{array}$ & Transversal & $\begin{array}{l}\text { Romanian employees } \\
\text { Invisible }\end{array}$ & $\begin{array}{l}\text { Affects whole } \\
\text { workforce. } \\
\text { Specialization } \\
\text { according to market }\end{array}$ \\
\hline
\end{tabular}


Role of language

on recruitment

Role of language on promotion

High in upper echelons.

Unimportant in

lower echelons
High for management. High for engineers

and white collar

workers

Low for rest

High in upper and

intermediate echelons.

Unimportant in lower

echelons
Very high in all cases Very low

High

8

$\Omega$

¿ू

High in upper

Low

Low

Unimportant for

professionals

(external markets) 
the subordinated linguistic group. In the cases analyzed, the corporate language is that which fulfills the functions of prestige and identity within the firm. In the case of ethnocentric firms, the language is German, while in the case of the industrial cluster, the language is Catalan. In terms of benefits, the strategy allows the creation of certain shared values and norms among management, which increases the cohesion of and trust within the group. In terms of negative effects, mention must be made of the conflicts between the autochthonous management personnel of the subsidiaries and management from the same national background as the parent company. At the same time, mistrust among the autochthonous managers and blue-collar staff increases towards this national elite, which is made worse currently in Spain by threats to delocalize production to Eastern Europe. We have defined this setting as one of a zero-sum game in which the utility function is derived from control. The resources to be allocated are limited and fixed. It must be noted that reinforcing linguistic barriers is especially viable in Fordist industrial models due to the fact that productive efficiency and effectiveness do not depend on linguistic factors, but on a high degree of specialization and separation between professional groups.

Table 6. Strategy 1: reinforcing linguistic barriers as a means of segmenting resources

\begin{tabular}{|c|c|c|}
\hline Settings & $\begin{array}{l}\text { Multinational ethnocentric } \\
\text { companies }\end{array}$ & Industrial cluster \\
\hline Resources at stake & \multicolumn{2}{|c|}{ Distribution of benefits and professional positions } \\
\hline Perception of game & \multicolumn{2}{|c|}{ Zero sum game. Criterion of maximization of control } \\
\hline $\begin{array}{l}\text { Groups that benefit } \\
\text { from the strategy }\end{array}$ & $\begin{array}{l}\text { EU workers in subsidiaries } \\
\text { of ethnocentric } \\
\text { multinational companies }\end{array}$ & $\begin{array}{l}\text { Autochthonous workers of } \\
\text { local production systems }\end{array}$ \\
\hline $\begin{array}{l}\text { Groups negatively } \\
\text { affected by the } \\
\text { strategy }\end{array}$ & $\begin{array}{l}\text { Autochthonous workers, } \\
\text { especially management }\end{array}$ & $\begin{array}{l}\text { Workers from non-EU } \\
\text { Eastern Europe }\end{array}$ \\
\hline $\begin{array}{l}\text { Intervening structural } \\
\text { elements }\end{array}$ & $\begin{array}{l}\text { Strategy supported by parent } \\
\text { company. High capacity } \\
\text { for financial capital } \\
\text { mobility }\end{array}$ & $\begin{array}{l}\text { Legal framework } \\
\text { discriminates against } \\
\text { non-EU citizens }\end{array}$ \\
\hline \multirow[t]{2}{*}{$\begin{array}{l}\text { Main problems from a } \\
\text { corporate point of } \\
\text { view }\end{array}$} & $\begin{array}{l}\text { Conflicts between parent- } \\
\text { company and subsidiary } \\
\text { management }\end{array}$ & $\begin{array}{l}\text { Waste of human capital of } \\
\text { the workers from Eastern } \\
\text { Europe }\end{array}$ \\
\hline & $\begin{array}{l}\text { Impossible for blue-collar } \\
\text { workers to participate in } \\
\text { the corporate culture }\end{array}$ & $\begin{array}{l}\text { Inability to gain access to } \\
\text { external markets }\end{array}$ \\
\hline $\begin{array}{l}\text { Main benefits from a } \\
\text { corporate point of } \\
\text { view }\end{array}$ & \multicolumn{2}{|c|}{$\begin{array}{l}\text { Norms and values shared, with a high degree of trust between } \\
\text { co-national management of the parent company or owners } \\
\text { of the capital }\end{array}$} \\
\hline
\end{tabular}


In Strategy 2, which we have defined as the bearing of the transaction costs, language is a key variable in the production process. By means of language policy, attempts are made to guarantee efficiency in the relation with clients and in internal management. Linguistic capital is highly valued in recruitment practices. Preference is given to the employment of trilingual personnel: the languages where the subsidiary is located (Spanish and/or Catalan, to a certain extent devalued due to their low level of value in global terms; the contact language with the market); English (the language of technical and horizontal coordination in the company), and, especially, the languages of the foreign consumer markets with marketing value. In the public health SMEs, the language of coordination and that of the international clients tends to coincide due to the tendency towards ethnolinguistic segmentation of the firms. In this respect, it is not so much a question of the mobilization of symbols or identities in order to reaffirm control over the market, but rather of maximizing communication efficiency with patients or clients. The result is one of win-win; by overcoming linguistic barriers, there is an increase in benefits for everyone at the same time. Workers are rewarded for their linguistic capital, and firms can undertake an overall reorganization of their services and reach clients from different linguistic backgrounds. Discrimination is exercised during the recruitment of personnel and not in the processes of promotion, thus favoring internal cohesion within the firm.

\section{Conclusions}

The different dynamics of the settings of business coordination that we have analyzed allow us to affirm that different forms of organizing production and position with respect to factor mobility bring with them different evaluations of the utility of languages, strategies, and linguistic outcomes. Thus, factor mobility does not necessarily lead to linguistic homogenization, but rather to diversification tainted with inequality. In fact, we have observed how in different settings a high degree of inequality arises in professional promotion (Strategy 1) or recruitment (Strategy 2) based on the linguistic capital of personnel. Thus recruitment and promotion, when based on linguistic criteria, involve forms of occupational stratification that affect the different linguistic groups.

We have observed how linguistic intensity and the central role of knowledge in the production process (and, in general, in today's society) place languages at the center of value creation. The new forms of organizing work, which involve flatter hierarchies within organizations with fewer intermediate posts, and the move away from organization by functions to 
Table 7. Strategy 2: Linguistic strategy aimed at overcoming linguistic barriers as a means of promoting corporate efficiency and effectiveness

\begin{tabular}{|c|c|c|}
\hline Settings & $\begin{array}{l}\text { Geocentric multinational } \\
\text { firms and those in transition }\end{array}$ & Internationalized SMEs \\
\hline Resources at stake & $\begin{array}{l}\text { Increase in profit allowing } \\
\text { delocalization of global } \\
\text { services for the company } \\
\text { and customers }\end{array}$ & $\begin{array}{l}\text { Increase in profit through the } \\
\text { overcoming of linguistic } \\
\text { barriers in those markets at } \\
\text { which the goods and services } \\
\text { are aimed }\end{array}$ \\
\hline Perception of game & \multicolumn{2}{|c|}{ Win-win game. Criteria of efficiency and effectiveness } \\
\hline Groups that benefit & \multicolumn{2}{|c|}{ The management of the firm, regardless of their national origins } \\
\hline from the strategy & $\begin{array}{l}\text { Trilingual personnel, highly } \\
\text { valued by the strategy of } \\
\text { global management }\end{array}$ & $\begin{array}{l}\text { Bilingual personnel, highly } \\
\text { valued due to their } \\
\text { specialization in a market of } \\
\text { foreign customers }\end{array}$ \\
\hline $\begin{array}{l}\text { Groups negatively } \\
\text { affected by the } \\
\text { strategy }\end{array}$ & \multicolumn{2}{|c|}{ Autochthonous workers with no linguistic capital } \\
\hline $\begin{array}{l}\text { Intervening structural } \\
\text { elements }\end{array}$ & $\begin{array}{l}\text { Linguistic intensification of } \\
\text { the production processes. } \\
\text { Increasingly global } \\
\text { management of production } \\
\text { processes }\end{array}$ & $\begin{array}{l}\text { Linguistic transformation of } \\
\text { local markets. Mobility of } \\
\text { EU citizens (tourists of } \\
\text { retirement age) }\end{array}$ \\
\hline $\begin{array}{l}\text { Main problems from } \\
\text { a corporate point } \\
\text { of view }\end{array}$ & $\begin{array}{l}\text { Reorganization of production } \\
\text { in multinational firms in } \\
\text { order to face the challenges } \\
\text { of global competition }\end{array}$ & $\begin{array}{l}\text { Lack of linguistic capital } \\
\text { among the autochthonous } \\
\text { population in the languages } \\
\text { of export markets (different } \\
\text { from the English language) }\end{array}$ \\
\hline $\begin{array}{l}\text { Main benefits from a } \\
\text { corporate point of } \\
\text { view }\end{array}$ & $\begin{array}{l}\text { Global management } \\
\text { overcoming cultural and } \\
\text { linguistic barriers }\end{array}$ & $\begin{array}{l}\text { Specialization and trust in } \\
\text { customer relations }\end{array}$ \\
\hline
\end{tabular}

organization by processes have meant an increase in the needs for horizontal communication between an ever greater number of workers. The entire workforce is expected to participate in production planning, as opposed to being limited to the repetitive carrying out of simple instructions. As such, firms reward workforces that internalize the needs for linguistic flexibility and pragmatism. This is the reason for the increase in the gap between those who, due to their language skills, enjoy advantages when participating in the generation of knowledge in international ambits and those who are unable to do so. This is especially the case in multinational corporations that undergo restructuring based on high value-added processes based on knowledge. These firms maintain and recruit trained workers whose linguistic capital allows a greater degree of internationalization and global coordination for the firm. In 
this respect, we have observed how not all workers are able to participate in such global coordination due to their lack of the appropriate linguistic capital, which leads to a segmentation of workforces according to their language skills. This represents a serious problem for those social strata that have not managed to invest in the most highly-valued linguistic resources.

Finally, the national origin of ownership represents a key variable in order to understand the relations of power between the different language groups. Positions of domination and subordination of certain languages over others can be explained, as we have been able to demonstrate, by the national and cultural origin of the firm. The unequal distribution of the corporate language means that language operates as an excellent control mechanism over access to resources (professional positions) within the firm. Not all workers are able to acquire, ceteris paribus, this company culture, and as such internationalization implies an iniquitous way of distributing resources for those who work for firms of the same national origin and those who work for foreign-owned firms. Recruitment and promotion of personnel comes to depend on the national origins of multinational firms, thus reproducing in the linguistic terrain the economic power of national groups in the international political context.

\section{Universidad Autónoma de Barcelona (Solé and Terrones) Universidad Rovira i Virgili (Alarcón and Garzón)}

\section{Notes}

* In this article we present the main results of a research project financed by the Institut d'Estudis Catalans that was carried out over the period 2002-2004 and was directed by Carlota Solé.

1. In order to validate our hypothesis by empirical observation we have chosen qualitative strategies. More specifically, we have conducted in-depth interviews (20) and discussion groups (10) made up of employees from sectors that we have considered to be particularly affected in socioeconomic terms by economic globalization and Economic and Monetary Union. We have analyzed the relation between three groups of workers: autochthonous, from the rest of the EU, and from outside the EU. In terms of settings, we have chosen the following: 1) ethnocentric multinational companies; 2) geocentric multinational companies; 3) an industrial cluster of Catalan-owned firms; and 4) smalland medium-sized firms providing health services. We have also included a reference to settings of transition between 1) and 2). 


\section{References}

Arrow, Kenneth J. (1972). Models of job discrimination. In Racial Discrimination in Economic Life, A. Pascal (ed), 83-102. Lexington: Heath.

Becker, Gary S. (1971). Economics of Discrimination. Chicago: University of Chicago Press.

Birsl, Ursula; Bitzan, Renate; Solé, Carlota; Parella, Sònia; French, Stephen; and Alarcón, Amado (2003). Migration und Interkulturalität in Großbritannien, Deutschland und Spanien. Europa und Nordamerika Serien, Vol. 10. Leverkusen: Leske Verlag.

Breton, Albert (1964). The economics of nationalism. Journal of Political Economy 62, 376-386.

- (1978). Nationalism and language politics. Canadian Journal of Economics 11, 656-668.

-; and Mieszkowski, Peter M. (1979). The economics of bilingualism. In The Political Economy of Fiscal Federalism, W. Oats (ed.), 261-273. Lexington: Lexington Books.

Carr, Jack (1985). Le bilingüisme au Canada: l'usage consacre-t-il l'anglais monopole naturel? In Economie et langue, François Vaillancourt (ed.), 27-37. Quebec: Documentation $\mathrm{du}$ Conseil de la langue française.

Christie, Helena; Hagen, Stuart; Sheikh, Haaris; Kenny, Breda; Chapman, Ian; van Staden, Mildo; Damsgaard, Lise; and Lindquist, Petrus (2001). European language and international strategy development in SMEs [ELISE] — European Overview Report. Report presented to the European Commission. www.stb.tno.nl/uploads/ELISEOverviewReport .pdf.

Church, Jeff; and King, Ian (1993). Bilingualism and network externalities. Canadian Journal of Economics 26, 337-345.

Coleman, James S. (1990). Foundations of Social Theory. Cambridge: The Belknap Press of Harvard University Press.

Colomer, Josep Maria (1990). The utility of bilingualism: a contribution to a rational choice model of language. Rationality and Society 2, 310-334.

De Swaan, Abraham (1993). The evolving European language system: a theory of communication potential and language competition. International Political Science Review 14, 241-255.

- (1998). A political sociology of the world language system (1): the dynamics of language spread. Language Problems and Language Planning 22(1), 63-75.

Dhir, Krishna S.; and Savage, Theresa (2002). The value of a working language. International Journal of the Sociology of Language 158, 1-35.

Dicker, Susan J. (1998). Adaptation and assimilation: US business responses to linguistic diversity in the workplace. Journal of Multilingual \& Multicultural Development 19, 282302.

European Commission (2002). La libre circulación de trabajadores: La plena realización de sus ventajas y sus posibilidades. COM/2002/0694 final.

Granovetter, Mark (1985). Economic action and social structure: the problem of embeddedness. American Journal of Sociology 91(3), 481-510.

Hagen, Stephen (ed.) (1997). Business Communication across Borders: A Study of Language Use and Practice in European Companies. London: Centre for Information on Language Teaching and Research, Languages National Training Organisation.

Harris, Richard G. (1998a). The economics of language in a virtually integrated economy. In New Canadian Perspectives. Changing the Language Landscape. Official Languages in Canada, Albert Breton (ed.), 35-88. Quebec: Department of Public Works and Government Services Canada.

-(1998b). Language and virtual economic integration. Paper presented on 30 May 1998 at the Canadian Economic Association Meetings, Ottawa, Canada. 
Hocevar, Touissaint (1975). Equilibria in linguistic minority markets. Kyklos 28, 33-57.

Kingscott, Geoffrey (1990). Every company must have a corporate language policy. In Corporate Language Policy, G. Kingscott and J. Matterson (eds.), 38-42. Nottingham: Praetorius.

Lang, Kevin (1986). A language theory of discrimination. Quarterly Journal of Economics 101, 363-382.

-(1993). Language and economists' theories of discrimination. International Journal of the Sociology of Language 103, 165-183.

Leblanc, Michel (1994). Une analyse économique des déterminants de la langue de travail des travailleurs francophones bilingues du Québec. In Actes du colloque sur la problématique de l'aménagement linguistique, Jean Dolbec and Helen Troestler (ed.), 569-588. Montréal: Office de la langue française.

Marschak, Jacob (1965). Economics of language. Behavioral Science 10, 35-40.

McManus, Walter S. (1985). Labor market costs of language disparity: an interpretation of Hispanic earnings differences. American Economic Review 75(4), 818-827.

Myers-Scotton, Carol (1982). Learning lingua francas and socioeconomic integration: evidence from Africa. In Language Spread: Studies in Diffusion and Social Change, R. Cooper (ed.), 63-94. Bloomington: Indiana University Press.

-(1993). Elite closure as a powerful language strategy: The African case. International Journal of the Sociology of Language 103, 149-163.

Pla Barber, Jose (1999). Coordination and control in multinational enterprises. New empirical evidence. Paper presented at Jornadas sobre Internacionalización, Universidad Complutense, Madrid.

Pool, Jonathan (1991). The world language problem. Rationality and Society 3, 78-105.

-(1993). Linguistic exploitation. International Journal of the Sociology of Language 103, $31-55$

Porter, Michel (1999). Els clusters a Catalunya. Quaderns de Qualitat de la Revista de Qualitat 34, 10-18.

Raynauld, André; and Marion, Gérald (1970). Une analyse économique de la disparité inter-ethnique des revenues. Revue economique 23, 1-19.

Solé, Carlota; and Alarcón, Amado (2001). Llengua i economia a Catalunya. Barcelona: Institut d'Estudis Catalans.

Vaillancourt, François (1985). Le choix de la langue de consommation. In Économie et Langue, F. Vaillancourt (ed.), 209-220. Quebec: Conseil de la langue française.

-(1989). The economics of language: an empirical validation of some theoretical predictions. Journal of the Society for Slovene Studies 11(1-2), 167-175.

- (1992). An economic perspective on language and public policy in Canada and the United States. In Immigration, Language, and Ethnicity: Canada and the United States, Barry R. Chiswick (ed.), 179-228. Washington, DC: AEI Press.

Van Parijs, Philliphe (2002). Linguistic justice. Politics, Philosophy and Economics 1, 59-74. - (2003). Europe's three language problems. Speech given on 4 April 2003 at the Universidad Pompeu Frabra, Barcelona. 